\title{
Literature Review : Gambaran Pengaruh Terapi Aktivitas Kelompok Sosialisasi Terhadap Kemampuan Bersosialisasi Pada Klien Isolasi Sosial
}

\author{
Nur Ardika ${ }^{*}$, Nurul Aktifah ${ }^{2}$ \\ 1,2 Prodi Diploma Tiga Keperawatan, Universitas Muhammadiyah Pekajangan Pekalongan, \\ Indonesia \\ *email: nrardika25@gmail.com
}

\begin{abstract}
Social isolation is a person's inability to interact with other people in his environment. Client feels rejected, isolated from others, and lonely. Moreover, he is not able to build meaningful relationships with other people. The client with this problem has difficulty to interact and socialize with others, and he even cannot communicate well. This paper aims to investigate the effect of socialization group activity therapy on the client with the problem stated above. The result of literature review stated from the pretest, it was obtained the average 12.07, and 20.9 after taking protest. Therefore, it could be concluded there is an effect of the therapy on sociability of social isolation clients. And, this is recommended for the nursing staff to apply this therapy in the client with the problem, so that they can improve their socialization skills.
\end{abstract}

Keywords: socialization group activity therapy; social isolation

\begin{abstract}
Abstrak
Isolasi sosial ialah suatu penurunan atau ketidakmampuan seorang individu berinteraksi dengan orang lain dengan lingkungan sekitarnya. Klien merasa ditolak, tidak diterima, kesepian, dan tidak mampu membina hubungan yang berarti dengan orang lain. Klien dengan isolasi sosial tidak mempunyai kemampuan untuk berosialisasi dan sulit mengungkapkan keinginan dan tidak mampu berkomunikasi dengan baik sehingga klien tidak mampu membina hubungan yang berarti dengan orang lain. Tujuan karya tulis ilmiah ini adalah untuk mengetahui seberapa berpengaruh terapi aktivitas kelompok sosialisasi pada klien isolasi sosial. Desain Karya tulis ilmiah ini adalah literature review. Hasil dari analisis didapatkan rata rata pre test sebesar 12,07, post test sebesar 20,9 dan didapatkan bahwa ada pengaruh Terapi Aktivitas Kelompok Sosialisasi (TAKS) terhadap kemampuan sosialisasi pada klien isolasi sosial. Kesimpulan ada pengaruh TAKS terhadap kemampuan sosialisasi pada klien isolasi sosial. Saran kepada tenaga keperawatan untuk memberikan TAKS pada klien isolasi sosial,sehingga kemampuan sosialisasi pada klien
\end{abstract}

Kata kunci: Terapi aktivitas kelompok sosialisasi (TAKS) ; isolasi sosial; interaksi sosial.

\section{Pendahuluan}

Manusia merupakan makhluk sosial, dimana tidak terlepas dari interaksi sosial. Disamping sebagai makhluk sosial juga perlu memiliki hubungan interpersonal yang positif, baik dengan lain maupun dengan lingkungannya. Hubungan interpersonal yang positif tersebut dapat terjadi apabila masing-masing individu mersa saling membutuhkan dan saling bergantung untuk membangun jati diri individu dalam lingkungan sosial yang kondusif. Seorang individu tidak akan mampu memenuhi hidupnya tanpa adanya hubungan dengan lingkungan sosialnya [1] Manusia dalam melakukan hubungan interpersonal kepuasan dapat tercapai jika salah satu individu secara aktif terlibat dalam proses interpersonal. Sebagai makhluk sosial manusia memerlukan interaksi sosial untuk berbagi rasa, bertukar pikiran dan kehendak, baik 


\section{Prosiding Seminar Nasional Kesehatan Lembaga Penelitian dan Pengabdian Masyarakat Universitas Muhammadiyah Pekajangan Pekalongan

secara langsung maupun tidak langsung. Ketidakmampuan individu dalam membina hubungan interpersonal yang baik bisa menyebabkan berbagai masalah yang kompleks. Jika masalah ini tidak ditangani lebih lanjut maka akan mengakibatkan gangguan jiwa.

Masalah gangguan jiwa menjadi salah satu asalah yang sangat serius diseluruh dunia. Penderita gangguan jiwa ada sekitar 450 juta orang (11\%) dari seluruh dunia dan paling tidak ada satu dari empat orang mengalami masalah mental [2] sedangkan menurut Kemenkes RI (2018) menunujukan data gangguan jiwa di Indonesia mengalami peningkatan yang signifikan dari tahun 2013 sampai 2018, naik dari 1,7 menjadi $7 \%$. Sehingga prevalensi gangguan jiwa diprediksi akan semakin meningkat setiap tahunnya. Gangguan jiwa adalah gangguan orak yang ditandai oleh terganggunya emsoi, proses berpikir, perilaku, dan persepsi (penangkapan panca indra). Gangguan jiwa ini menimbulkan hambatan dalam melaksanakan peran sebagai manusia[3]. Mulai dari perilaku menghindar dari lingkungan, tidak mau membina hubungan dengan orang lain, berdiam saja hingga berbicara dengan tidak jelas.

Uraian diatas menunjukkan banyaknya gangguan jiwa yang saat ini sering terjadi adalah dampak negatif dari isolasi sosial yang sering dikenal dengan skizofrenia. Terjadinya masalah ini dipengaruhi oleh factor predisposisi antaranya perkembangan dan sosial budaya. [4] menjelaskan kegagalan dapat menyebabkan individu tidak yakin pada diri sendiri, tidak percaya pada orang lain, ragu, takut salah, pesimis, putus asa, tidak mampu merumuskan keinginan dan merasa tertekan. Keadaan ini dapat menimbulkan perilaku tidak ingin berinteraksi dengan orang lain, lebih menyukai berdiam diri, menjauh dari orang lain serta kegiatan sehari-hari terabaikan.

Isolasi sosial ialah suatu penurunan atau ketidakmampuan seorang individu berinteraksi dengan orang lain dengan lingkungan sekitarnya, klien merasa ditolak, tidak diterima, kesepian dan tidak mampu membina hubungan yang berarti dengan orang lain. Klien dengan masalah isolasi sosial tidak mempunyai kemampuan untuk bersosialisasi dan sulit untuk mengungkapkan keinginan dan tidak mampu berkomunikasi dengan baik sehingga klien tidak mampu membina hubungan yang berarti dengan orang lain. Untuk mengatasi masalah tersebut maka harus ada intervensi lebih lanjut sebagai upaya memfasilitasi ketidakmampuan klien. Salah satu intervensi yang dapat mencegah keparahan pasien isolasi sosial adalah terapi aktivitas kelompok sosialisasi. Menurut [5] terapi aktivitas kelompok adalah suatu terapi modalitas yang dilakukan perawat kepada sejumlah klien dengan masalah keperawatan yang sama. Aktivitas digunakan sebagai terapi dan kelompok digunakan sebagai target asuhan. Salah satu terapi aktivitas kelompok untuk klien dengan masalah isolasi sosial ialah terapi aktivitas kelompok sosialisasi

Terapi aktivitas kelompok sosialisasi adalah terapi yang dilakukan perawat dalam upata memfasilitasi kemampuan sosialisasi klien secara bertahap dan interpersonal (satu dan satu), kelompok maupun masyarakat sekitar klien [5] Penelitian mengenai pengaruh terapi aktivitas kelompok sosialisasi pada pasien isolasi sosial oleh setya (2009) didapatkan adanya oeningkatan kemampuan berinteraksi dan menunjukkan adanya penurunan perilaku isolasi sosial setelah di berikan TAKS. Fenomena di atas 


\section{Prosiding Seminar Nasional Kesehatan Lembaga Penelitian dan Pengabdian Masyarakat Universitas Muhammadiyah Pekajangan Pekalongan}

membuat penulis tertarik untuk melakukan studi literatur tentang gambaran pengaruh terapi aktivitas kelompok sosialisasi pada klien isolasi sosial.

\section{Metode}

Metode atau rancangan karya tulis ilmiah ini menggunakan desain Literature Review, yakni sebuah sintesis dari studi literature yang bersifat sistemik, jelas, menyeluruh, dengan mengidentifikasi, menganalisis, mengevaluasi melalui pengumpulan data-data yang sudah ada dengan metode pencarian yang eksplisit dan melibatkan proses telaah kritis dalam pemilihian studi. Karya tulis ilmiah ini mereview 3 artikel tentang pengaruh terapi aktivitas kelompok sosialisasi terhadap kemampuan sosialisasi pada klien isolasi sosial.

\section{Hasil dan Pembahasan}

\section{Hasil}

Karakteristik demografi responden

Tabel 3.1 Data Demografi berdasarkan Karakteristik Responden

\begin{tabular}{ccc}
\hline Karakteristik & Frekuensi & Presentase (\%) \\
\hline Jenis kelamin $(n=22)$ & 16 & 73 \\
Laki- laki & 6 & 27 \\
Perempuan & 22 & 100 \\
Total & 7 & \\
Usia $(\mathrm{n}=22)$ & 15 & 32 \\
$18-25$ & 22 & 68 \\
$>25-40$ & & 100 \\
Total & 6 & 27 \\
Pendidikan $(n=22)$ & 10 & 46 \\
SD & 6 & 27 \\
SMP & 22 & 100 \\
SMA & & \\
Total & 4 & 40 \\
Pekerjaan $(n=10)$ & 6 & 60 \\
Bekerja & 10 & 100 \\
Tidak Bekerja & &
\end{tabular}

Hasil analisa tabel 3.1 menunjukan karakteristik responden dengan variabel jenis kelamin yang paling banyak adalah laki-laki sejumlah 16 (73\%) variabel usia yang paling banyak adalah 25-40 tahun sejumlah 15 (68\%), variabel Pendidikan yang paling banyak adalah SMP sejumlah 10 (46\%) sedangkan untuk variabel pekerjaan didapatkan mayoritas tidak bekerja sejumlah 10 responden (60\%)

Data kemampuan interaksi social.

Tabel 3.2 hasil Analisa Kemampuan Interaksi Sosial dengan Terapi Aktivitas Kelompok Sosialisas $(\mathrm{N}=52)$

\begin{tabular}{|c|c|c|c|c|c|c|}
\hline \multirow[t]{2}{*}{ No } & \multirow{2}{*}{$\begin{array}{c}\text { Artikel } \\
\text { Penulis } \\
\end{array}$} & \multirow[t]{2}{*}{$\mathrm{n}$} & \multicolumn{3}{|c|}{ Mean (rata-rata) } & \multirow[t]{2}{*}{$\mathrm{P}$ value } \\
\hline & & & Pre test & Post test & peningkatan & \\
\hline 1 & $\begin{array}{c}\text { Effendi, } \\
\text { Rahayuningsih } \\
\text { dan Muharyati } \\
\text { (2012) }\end{array}$ & 10 & 31,50 & 40,10 & 8,6 & 0,001 \\
\hline 2 & $\begin{array}{l}\text { Saswati dan } \\
\text { Sutinah } \\
\text { (2018) }\end{array}$ & 12 & 2,42 & 19,00 & 16,58 & 0,009 \\
\hline 3 & $\begin{array}{l}\text { Mashuda, } \\
\text { Hermansyah, } \\
\text { Efendi (2018) }\end{array}$ & 30 & 0,30 & 3,6 & 3,3 & 0,001 \\
\hline & Jumlah & & 12,07 & 20,9 & 8,83 & \\
\hline
\end{tabular}




\section{Prosiding Seminar Nasional Kesehatan Lembaga Penelitian dan Pengabdian Masyarakat Universitas Muhammadiyah Pekajangan Pekalongan

Hasil Analisa pada tabel 3.2 didapatkan kemampuan interaksi sosial pada artikel no 1 mengalami rata-rata peningkatan sebesar 8,6 sedangkan artikel no. 2 mengalami rata-rata peningkatan kemampuan interaksi sosial sebesar 14,58 , artikel no. 3 rata-rata peningkatan kemampuan interaksi sosial sebesar 3,3 dan nilai $p$ value masing-masing artikel $>0,005$. Hal ini menunjukkan bahwa ada pengaruh TAKS terhadap kemampuan sosialisasi klien isolasi sosial.

\section{Pembahasan}

\section{Karakteristik Responden}

Hasil Analisa didapatkan karakteristik responden pada tabel 1 meliputi jenis kelamin, usia dan Pendidikan dengan sampel sebanyak 22 orang dan pekerjaan dengan sampel 10 orang. Tabel 1 menunjukan bahwa responden dengan variabel jenis kelamin paling banyak adalah laki-laki sejumlah 16 orang dengan presentase $73 \%$. Hal ini disebabkan karena laki-laki sangat rentan terkena gangguan jiwa salah satu penyebabnya adalah tingginya tingkat emosional. Bahkan untuk gangguan ringan, lakilaki dua kali lebih berisiko disbanding perempuan [6].

Usia responden pada studi literature ini dibagi menjadi 2 kategori yaitu 18-25 tahun dan 25-40 tahun. Hasil tabel 1 menunjukkan bahwa Sebagian besar responden berumur 25-40 tahun sejumlah 15 orang (68\%). Hal ini sejalan dengan penelitian yang dilakukan oleh [4] pada variabel usia menunjukan bahwa $60 \%$ responden $25-40$ tahun. [6] menjelaskan bahwa gangguan jiwa cenderung diderita pada usia produktif karena pada usia tersebut lebih banyak merasakan stress dan depresi. Hal ini sejalan dengan faktor presipitasi stressor psikologi dijelaskan oleh [7] insensitas ansietas yang ekstrim dan memanjang disertai dengan terbatasnya kemampuan individu untuk mengatasi masalah akan menimbulkan berbagai masalah gangguan berhubungan pada tipe psikotik.

Karakteristik responden menurut tingkat Pendidikan pada tabel 1 menunjukan mayoritas tingkat Pendidikan adalah SMP yaitu sejumlah 10 responden (46\%). Hasil penelitian [2] di Panti Sosial Rehabilitasi Gelandangan dengan Orang Gangguan Jiwa dari 18 responden didapatkan bahwa mayoritas responden tidak sekolah sebanyak 10 orang $(55,6 \%)$, sisanya berpendidikan SD sebanyak 1 orang $(5,6 \%)$, SMP sebanyak $(11,1 \%)$ serta SMA sebanyak 5 orang $(27,8 \%)$. Tingkat Pendidikan rendah pada sesorang akan menyebabkan orang tersebut mudah mengalami kecemasan, semakin tinggi tingkat Pendidikan seseorang akan berpengaruh dalam kemampuan berpikir seseorang.

Karakteristik responden menurut pekerjaan didapatkan hanya 1 artikel dengan jumlah responden 10 orang didapatkan hasil sejumlah 6 orang $(60 \%)$ yang tidak bekerja. [4] menjelaskan bahwa bekerja merupakan salah satu dimensi kehidupan yang penting. Mereka bekerja dengan berbagai alasan seperti untuk mendapatkan kepuasan pribadi, penghasilan dan status sosial. Pernyataan tersebut sejalan dengan teori yang dijelaskan oleh [8] bahwa faktor predisposisi secara sosial budaya adalah masalah pekerjaan dimana klien sulit mendapatkan pekerjaan sehingga berdampak pada masalah ekonomi yang dialami oleh klien artinya bagi seseorang yang tidak bekerja dan tidak mampu menangani stressor yang ada, dalam suasana hati yang demekian ia merasa sedih, pesismis merisaukan masa depan dan merisaukan 


\section{Prosiding Seminar Nasional Kesehatan Lembaga Penelitian dan Pengabdian Masyarakat Universitas Muhammadiyah Pekajangan Pekalongan}

kesehatanya terlalu tidak wajar. minatnya berkurang dan perhatiannya tidak lagi terpusat pada kegiatan-kegiatan yang digemari merasa dunia sebagai tempat yang menyedihkan dan tidak dapat membayangkan perbaikan-perbaikan di kemudian hari atau mengingat saat-saat dimana ia merasa gembira dan puas. Selera makan berkurang dan berat badannya mulai menurun. Tidurnya hamper selalu terganggu dan keluhan yang paling sering adalah terbangun dini hari dan tidak dapat tidur sesudahnya dengan berkembangnya depresi seseorag menjadi lebih lamban, merasa sedih dan mungkin terlalu dihantui rasa bersalah dan tidak berguna.

\section{Kemampuan Sosialisasi}

Hasil literature review pada tabel 4.2 didapatkan rata-rata peningkatan kemampuan sosialisasi klien isolasi sosial setelah dilakukan terapi sebesar 8,83 peningkatan tertinggi didapatkan pada artikel no.2 sedangkan hasil peningkatan kemampuan sosialisasi paling rendah didapatkan pada artikel no.3 karena pada artikel no.3 jumlah responden menggunakan kelompok besar. Hal ini sejalan dengan teori yang dijelaskan oleh Stuart dan Laraia [4] yang menjelaskan bahwa kelompok efektif untuk TAK adalah kelompok kecil agar terapi yang dilakukan terintegrasi, efektif dan dan waktu yang dibutuhkan untuk menyelesaikan masalah klien lebih cepat

Hasil literature review dari ketiga artikel didapatkan nilai $p$ value $<0,005$. Hasil tersebut dapat diartikan bahwa ada pengaruh TAKS dalam peningkatan kemampuan sosialisasi klien isolasi sosial. Hasil studi literatur menunjukan bahwa sebelum dilakukan TAKS semua responden kurang mampu berinteraksi sosial. Hal ini disebabkan karena tidak adanya tindakan atau stimulus yang dilakukan untuk mengubah perilaku maladaptive serta lingkungan yang kurang teraupetik seperti pasien yang terlalu banyak dalam ruang perawatan dan kadang mendapatkan tekanan dari pasien lain . Hal ini sesuai dengan teori bahwa lingkungan berkaitan sangat kuat dengan stimulus psikologi seseorang yang berdampak pada kesembuhan, karena lingkungan tersebut akan memberikan dampak baik pada kondisi fisik maupun kondisi psikologi sesorang [8]

\section{Kesimpulan}

Hasil dari studi literature gambaran pengaruh terapi aktivitas kelompok sosialisasi terhadap kemampuan bersosialisasi pada klien isolasi sosial menunjukan adanya peningkatan kemampuan sosialisasi setelah diberikan terapi. Hal tersebut menunjukan bahwa terapi aktivitas kelompok sosialisasi berpengaruh terhadap kemampuan sosialisasi pada klien isolasi social.

\section{Referensi}

[1] J. D. T. Donsu, Psikologi keperawatan. Yogyakarta, Indonesia: Pustaka Baru, 2019.

[2] D. Purnama Sari, S. Maryatun, P. Ilmu Keperawatan, F. Kedokteran, U. Sriwijaya, and D. Jiwa, "Seminar Nasional Keperawatan 'Pemenuhan Kebutuhan Dasar dalam Perawatan Paliatif pada Era Normal Baru' Tahun 2020 Dengan Gangguan Jiwa The Effects Of Therapeutic Activity Group Socialization On Social Interaction Capability And Activity Daily Living Social Isolation Clients At Social 


\section{Prosiding Seminar Nasional Kesehatan Lembaga Penelitian dan Pengabdian Masyarakat Universitas Muhammadiyah Pekajangan Pekalongan

Institutions Rehabilitation Of Beggars Of Homeless People With Mental Disorders $1 * . "$

[3] Sutejo, Keperawatan Jiwa Prinsip dan Praktik Asuhan Keperawatn Jiwa. Yogyakatya, Indonesia: Pustaka Baru Press, 2018.

[4] S. Efendi, A. Rahayuningsih, W. Muharyati, and R. Hb Sa'anin Padang, "Pengaruh Pemberian Terapi Aktivitas Kelompok Sosialisasi Terhadap Perubahan Perilaku Klien Isolasi Sosial."

[5] Keliat and B. Anna, Keperawatan Jiwa Terapi Aktivitas Kelompok. Jakarta, Indonesia: Penerbit Buku Kedokteran EGC, 2016.

[6] K. X. Wilayah, N. Saswati, P. Studi Ilmu Keperawatan, and P. Studi Ners, "301)," Jurnal Endurance, vol. 3, no. 2, p. 292, 2018, doi: 10.22216/jen.v3i1.2492.

[7] Sutejo, Keperawatan Jiwa Konsep dan Praktik Asuhan Keperawatan Kesehatan Jiwa: Gangguan Jiwa dan Psikososial. Yogyakarta, Indonesia: Pustaka Baru Press, 2019.

[8] Dermawan Deden and Rusdi, Keperawatan Jiwa Konsep dan Kerangka Kerja Asuhan Keperawatan Jiwa. Yogyakarta, Indonesia: Gosyen Publishing, 2013. 